\title{
Changing Epidemiology and Future Challenges of Inflammatory Bowel Disease in Asia
}

\author{
Siew C Ng, MBBS, MRCP, Ph.D. \\ Institute of Digestive Disease, Chinese University of Hong Kong, Hong Kong
}

In the past decade, many countries in Asia, in particularly in East Asia, are experiencing a progressive rise in the incidence and prevalence of inflammatory bowel disease (IBD). Improved physician awareness and diagnostic methods are unlikely to fully account for this rapid increase. This epidemiological shift is likely to relate to industralization, westernization of lifestyles and changes in eating habits, as part of the socioeconomic development in Asia, although many of these putative environmental factors have not been formally investigated in Asian cohorts. Genetic factors for IBD differ between Asia and the West. NOD2/CARD15 mutation, repeatedly observed in the Caucasian populations, is not associated with Crohn's disease in Asian populations. Familial clustering is generally uncommon in Asia but it is expected to increase as the IBD prevalence in this region rises. Ethnic-racial differences of IBD have been described and Indians appear to be most affected in South-East Asia. Clinical manifestation of IBD in Asia resemble the Western population in general, but with some differences, including higher prevalence of males and ileocolonic disease, lower disease severity, surgical rates and extraintestinal manifestations. These differences may relate to time factor, genetic background and environmental factors. This review summarises recent epidemiological data of IBD including environmental factors associated with the development of IBD in Asia. Future research focusing on studying the epidemiology of IBD in an area of rapidly increasing prevalence such as Asia will allow the opportunity to identify potential risk factors and provide a better understanding of the aetiology of disease in the Asian population. (Intest Res 2010;8:1-8)

Key Words: Inflammatory Bowel Disease; Asia; Epidemiology; Genetics; Environmental Factors

\section{BACKGROUND}

Crohn's disease (CD) and Ulcerative colitis (UC) are chronic inflammatory bowel diseases (IBD) of unknown aetiology. The pathophysiology of IBD relates to a dysregulated mucosal immune response to antigenic stimulation from gut microbiota on a background of genetic susceptibility. ${ }^{1}$ IBD represents an important public health problem because it affects mostly young people at an age when they are most active in their private and professional lives, ${ }^{2}$ and a management challenge because of its unpredictable relapsing nature. During the last few decades the incidence of IBD has

Received April 20, 2010. Accepted May 29, 2010.

- Correspondence to : Siew C Ng, MBBS, MRCP, Ph.D., Institute of Digestive Disease, Department of Medicine and Therapeutics, Chinese University of Hong Kong, Hong Kong

Tel: +852-2637-3509, Fax: +852-2646-8915

E-mail: siewchienng@cuhk.edu.hk changed in many ways. Incidence rates of traditionally high incidence areas such as Western Europe is relatively stable or even decreasing, ${ }^{3}$ while diseases have become more prevalent in previously low incidence areas, such as Asia and Eastern Europe. ${ }^{4-7}$

The reason for these changes remains unknown. They are unlikely to be merely increased awareness of the disease and differences in diagnostic practices, but most likely reflect real differences secondary to environmental factors, lifestyle changes and genetic factors. ${ }^{8}$ Genetic susceptibility is different in Asian compared to Western patients. ${ }^{7}$ Apart from geographic differences, ethnic differences have been described in multi-racial countries including Malaysia and Singapore. Indians appeared to be more susceptible to IBD than Chinese and native Malays.'

Half the world's population reside in the Asia-Pacific region and the continuing rise in incidence of IBD will have important implications for health care providers in 
many Asian countries who will need to address both health needs of patients and the social burden of these chronic diseases. $^{10-13}$ The epidemiology and clinical characteristics of IBD in Asia has been recently reviewed in two comprehensive reviews, ${ }^{7,14}$ and consensus for the management of IBD from several counties in Asia Asia has been published. ${ }^{15-18}$ In this paper, I have provided an update on the incidence and prevalence of IBD, and susceptibility genes identified to date in studies from Asia. Environmental factors that may play a role in the rising incidence of IBD in this region were reviewed. Clinical features and complications of IBD in Asia were compared with the West, and clinical challenges and future research questions were discussed.

\section{INCIDENCE AND PREVALENCE}

The incidence rates of $\mathrm{CD}$ and UC vary worldwide between 0.1 to 16 per 100,000 inhabitants and 0.5 to 24.5 per 100,000 inhabitants, respectively. ${ }^{19,20}$ IBD is more common in the Northern than the Southern part of the world, and it is more common among Caucasian compared with non-caucasian populations. The highest incidence rates have been recorded in North America and North and West Europe, while lower rates have been reported in South America, Africa and Asia. ${ }^{21}$ The incidence of IBD in Australia has recently been shown to equal to the highest in the world. ${ }^{22}$ Epidemiological studies in the West have shown that the increase in incidence of UC precedes the increase of incidence of CD by about 15 to 20 years. $^{23-25}$

In Asia, several studies have indicated a rising trend of the incidence and prevalence of IBD although only few data are available on the true epidemiology of IBD in Asia. ${ }^{7}$ Studies reporting the incidence of IBD in Asia have been derived mostly from hospital based database in which confirmed cases of IBD were extrapolated to the area that the hospital serves with the population in that area used as a denominator. Japan is the only country in Asia that has a national IBD registry maintained by the Ministry of Health, Labour and Welfare. Data reporting time trend increase in the incidence of IBD in Asia are now available. ${ }^{26-29}$ In Japan, cumulative numbers of IBD patients has risen by three-fold. The estimated annual incidence of CD in Japan have increased from approximately 0.6 per 100,000 in 1986 to 1.2 per 100,000 population in $1998 .^{30}$ In Hong Kong, there is a three-fold increase in the incidence of $\mathrm{CD}$ in Chinese patients from 0.3 per 100,000 in 1986 to 1 per

Table 1. Incidence and Prevalence of IBD in Asia

\begin{tabular}{|c|c|c|c|c|c|c|}
\hline \multirow{2}{*}{ Authors } & \multirow{2}{*}{ Country } & \multirow{2}{*}{ Years } & \multicolumn{2}{|c|}{ Incidence } & \multicolumn{2}{|c|}{ Prevalence } \\
\hline & & & CD & UC & CD & UC \\
\hline Higashi et al. $1988^{36}$ & Japan & 1984-1985 & - & - & 1.86 & 7.85 \\
\hline Yoshida et al. $1990^{26}$ & Japan & 1965 & 0.01 & 0.08 & 5.85 & 5.5 \\
\hline Morita et al. $1995^{37}$ & Japan & 1991 & 0.51 & 1.95 & 5.85 & 18.12 \\
\hline Yao et al. $2000^{30}$ & Japan & 1998 & 1.2 & - & 13.5 & - \\
\hline \multirow[t]{4}{*}{ Yang et al. $2008^{27,38}$} & South Korea & $1986-1990$ & 0.05 & 0.34 & - & - \\
\hline & & 1991-1995 & 0.22 & 0.87 & - & - \\
\hline & & 1996-2000 & 0.52 & 1.74 & - & 7.57 \\
\hline & & $2001-2005$ & 1.34 & 3.08 & 11.24 & 30.87 \\
\hline Sung et al. $1994^{39}$ & Hong Kong & 1994 & - & - & 1.3 & - \\
\hline Leong et al. $2004^{28}$ & Hong Kong & 1999-2001 & 1.0 & 1.2 & - & - \\
\hline \multirow[t]{3}{*}{ Lok et al. $2008^{40}$} & Hong Kong & 1997 & - & 0.35 & - & 2.3 \\
\hline & & 2001 & - & 0.85 & - & 4.9 \\
\hline & & 2006 & - & 0.40 & - & 7.0 \\
\hline Zheng et al. $2005^{41}$ & China & 1950-2000 & 0.28 & - & 1.38 & - \\
\hline Lee et al. $2000^{33}$ & Singapore & 1999 & - & - & 3.6 & 6.0 \\
\hline Thia at al. $2006^{42}$ & Singapore & 2004 & - & - & 7.2 & - \\
\hline Sood et al. $2003^{32}$ & North India & 1999-2000 & - & 6.02 & - & 44.3 \\
\hline Niriella et al. $2010^{43}$ & Sri Lanka & 2007-2008 & 0.09 & 0.69 & 1.2 & 5.3 \\
\hline
\end{tabular}

IBD, inflammatory bowel disease; CD, Crohn's disease; UC, ulcerative colitis. 
100,000 in 1991-2001. In China, a four-fold increase in the prevalence of IBD since the 1990s have been observed. $^{31}$

Only very few population-based IBD studies exist in the Asian population. One study in India performed a community based survey in random selected districts in Punjab and reported a crude incidence for UC of 6.02 cases per 100,000 inhabitants. ${ }^{32}$ This figure is likely to be an underestimation of the true prevalence of UC as not all patients had a sigmoidoscopy or biopsy to confirm disease. Another population-based study in Korea has shown a steady rise in the mean annual incidence of $\mathrm{CD}$ and $\mathrm{UC}$ in the Songpa-Kangdong district of Seoul from 0.05 and 0.34 per 100,000 inhabitants, respectively, in 1986-1990 to 1.34 and 3.08 per 100,000 inhabitants, respectively, in 2001-2005..$^{27}$ In countries of multi-ethnic population such as Singapore and Malaysia, Indians have a higher prevalence of UC and $\mathrm{CD}$ than Chinese and Malays. ${ }^{33-35}$ Overall, published studies in Asia have confirmed that the incidence and prevalence of both $\mathrm{UC}$ and $\mathrm{CD}$ are increasing in Asia although the reported rates are still lower that in North America and Europe. There is also a time lag phenomenon compared to time trends in the West. Table 1 shows the incidence and prevalence of $\mathrm{CD}$ and UC from studies derived mostly from East Asia and South-East Asia.

\section{GENETICS}

Variation is evident in the genetic susceptibility for IBD between Asian and the White population. For instance, nucleotide oligomerization domain-2 (NOD2/CARD 15) variants which account for approximately $20 \%$ of $C D$ in white and Jewish populations ${ }^{44,45}$ have not been detected in studies of IBD subjects from Hong Kong, ${ }^{46}$ China, ${ }^{47}$ Japan $^{48}$ and Korea. ${ }^{49,50}$ In addition IL-23 receptor (IL-23R) and autophagy-related 16-like 1 (ATG16L1) genes which have been firmly associated with $\mathrm{CD}$ in the White population, ${ }^{51,52}$ were reported to have no assocations with $\mathrm{CD}$ in Japanese ${ }^{53}$ and Korean patients. ${ }^{54}$ Susceptibility loci on IBD5 locus and IRGM genes are also not associated with CD in Japanese. ${ }^{55,56}$ For UC, several susceptibility genes have been identified in the Caucasian populations which have not been associated with the Asian populations. ${ }^{57-59}$ In India, potential associations between UC and SNP5 in the North Indian populations suggest that there is allelic heterogeneity in UC susceptibility. ${ }^{60}$ Racial variation is evident suggesting host genetic predisposition. Indians in South East Asia are more proned towards the development of IBD than Chinese and Malays. $^{61}$ Table 2 shows the genetic susceptibility loci in Asian IBD patients.

Compared with Caucasians, familial clustering for both $\mathrm{CD}$ and $\mathrm{UC}$ is rare in Asian patients. ${ }^{7,9,62} \mathrm{~A}$ family history of IBD has been reported in up to $3 \%$ and $10 \%$ of UC and CD patients in Asian studies. ${ }^{27-29,33,40,63}$ This lower rates of familial aggregration in Asia is most likely related to the overall low disease prevalence, and as disease prevalence increases with time, the attributable risk of a positive family history is likely to be similar in Asian and Caucasian patients. ${ }^{64}$

\section{ENVIRONMENTAL FACTORS}

Changes in lifestyle in Asia during the last two decades have resulted in a more "westernized" standard way of living, with increased consumption of refined sugar, fatty acids, fast food, cereals and bread and reduced consumption of fruit, vegetables and fibres. ${ }^{82,83}$ With all of these aspects of westernization previously being associated with $\mathrm{IBD}^{84,85}$ westernization of lifestyle could potentially explain the observed increases

Table 2. IBD Susceptibility Genes Associated with the Asian Population

\begin{tabular}{|c|c|c|}
\hline Ethnicity & Associated with CD & Associated with UC \\
\hline Japanese & $\begin{array}{l}\text { TNFSF15 } \\
\text { DLG5 } \\
\text { 66 }\end{array}$ & $\begin{array}{l}\text { CTLA }-4^{67} \\
\text { HLA-DRB } 1 * 1502^{68} \\
\text { HLA B5 DR2 }{ }^{69}\end{array}$ \\
\hline South Koreans & $\begin{array}{l}\text { TNFSF15 } 5^{70} \\
\text { IL-23R }^{54}\end{array}$ & $\begin{array}{l}\text { HLA-DRB1*1502, } \\
\text { DR2 alleles }{ }^{71}\end{array}$ \\
\hline Han Chinese & $\mathrm{IL}-23 \mathrm{R}^{72}$ & $\begin{array}{l}\text { CTLA }-4^{73-75} \\
\text { MCP- } 1^{76} \\
\text { IL-1Beta } \\
\text { MICB0106 } \\
\text { MICA } * \text { A5.1 allele } \text { a }^{78,79} \\
\text { IL-17F } 7488-A^{80}\end{array}$ \\
\hline $\begin{array}{l}\text { Indians } \\
\text { Malaysians }\end{array}$ & $\stackrel{-}{\text { NOD2/CARD15 }}{ }^{61}$ & MDR1 gene ${ }^{81}$ \\
\hline
\end{tabular}

$\mathrm{IBD}$, inflammatory bowel disease; CD, Crohn's disease; UC, ulcerative colitis. 
of incidence of $\mathrm{UC}$ and $\mathrm{CD} .^{20,82,86}$ In Japan, the increased intake of diary products and meat has paralleled the rising trend of $\mathrm{UC}^{29}$ and a higher consumption of sweets and high fat diet has been associated with $\mathrm{UC}$ and $\mathrm{CD}{ }^{87}$

Other more controversial risk factors such as tonsillectomy, perinatal infections, oral contraceptives, breastfeeding and vaccinations have been proposed as being associated with IBD, but these factors have not been studied in the Asian cohorts. The only factors that have been proven to be important environmental factors in both UC and CD in studies from the West are smoking and appendectomy. Small studies in East Asia however have not shown an association between smoking and $\mathrm{CD}{ }^{28,88}$ Conversely the protective effect of smoking on UC had been confirmed in studies from Japan and China. ${ }^{37,89}$ Consistent with Western data, case-control studies in Asia has demonstrated the protective effect of appendectomy in $\mathrm{UC}^{89,90}$ Overall, Asian populations probably has genetic susceptibility, that when exposed to putative environmental factors will develop IBD. This predisposition appears to be stronger in certain racial groups.

\section{CLINICAL CHARACTERISTICS}

Clinical manifestation of IBD in Asia is relatively similar to that of the West although disease severity may be less in Asia. A few studies have reported differences in the clinical phenotypes and complications of IBD, including higher prevalence of ileocolonic involvement in $\mathrm{CD}$, lower surgical rates, and a low frequency of primary sclerosing cholangitis among IBD patients in Asia. ${ }^{7,14}$ Differences in disease, severity and complications may relate to genetic background, environmental factos such as diet and intestinal flora, and the duration of disease. ${ }^{7}$ The peak age of disease onset in Asia is 20 to 50 years, and a second peak after 50 years old is less common in Asian patients. ${ }^{91}$ Combined small and large bowel involvement appears to be most common in East Asia. In South and West Asia, distribution of disease site is more variable. ${ }^{9,27,62}$ Extraintestinal manifestations are less common in Asian populations. Table 3 summarises the clinical features of IBD in Asian compared with the Western population.

\section{CURRENT CHALLENGES AND FUTURE DIRECTIONS}

Current major clinical challenge relates to the accurate diagnosis of IBD in countries with a high background prevalence of infections. The diagnosis of $\mathrm{CD}$ in geographical areas where tuberculosis is common poses a diagnostic challenge. Infections may mimic IBD, and can complicate the course of existing IBD. Limited availability of diagnostic tests in particularly radiological imaging may delay diagnosis. Screening for latent infections specifically for tuberculosis and

Table 3. Clinical Features of IBD in Asia and the West

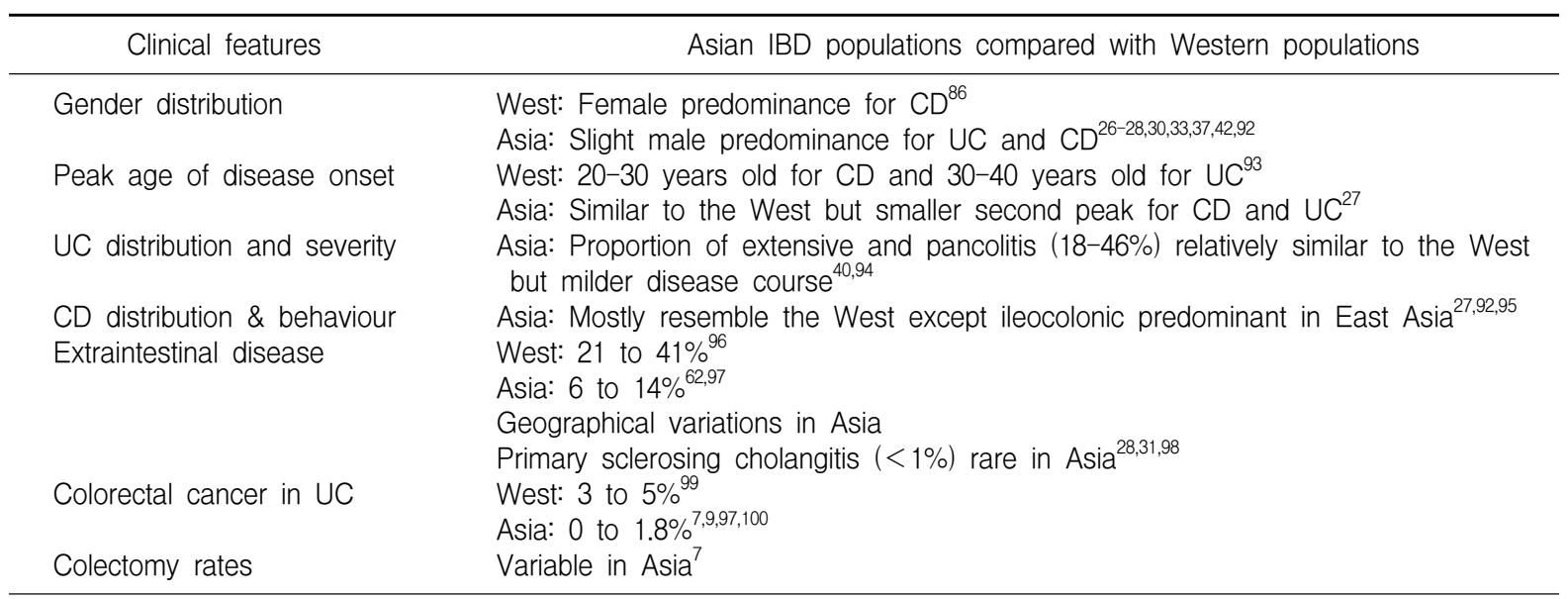

IBD, inflammatory bowel disease; CD, Crohn's disease; UC, ulcerative colitis. 
hepatitis B deserve special consideration in Asia given the high prevalence of these diseases in the Asian populations. Recently biological theapy has entered the armamentarium of IBD, and the efficacy and side effects of biologics in Asian cohorts warrant further investigations. There is also a diverse medical practice in South Asia and South East Asia which include alternative and complementary medicine, Ayurveda, Homeopathy, and some patients with IBD may prefer to present to traditional and alternative health practitioners.

With the exception of Japan, Asia currently lacks population based registries of IBD. Contraints in health care resources have made the conduct of an epidemiological study in developing countries a challenge. Larger epidemiological data over time are necessary to describe the true incidence of IBD and further characterize the clinical features and risk factors of IBD in different geographical areas in the Asia-Pacific region. The conduct of an epidemiology study in Asia requires good case ascertainment in a well defined area with known denominator. Such studies will better define the burden of illness, explore the mechanism of association with environmental factors as well as identify new risk factors. Future studies to determine whether smoking plays a lesser role in the development of CD in Asian populations are needed. Studying exposure and risk factors for IBD require prospectivey collected data from questionnaires on diet and environmental exposure in order to minimise recall bias and incomplete data. A large scale web-based epidemiology study (EpiCOM) organised by the European Crohn's and Colitis Organisation (ECCO) is currently in progress in East and West Europe. A second project known as the Origin study, also onducted by ECCO, aims to prospectively recruit first degree relatives of probands with $\mathrm{CD}$ and follow them for at least ten years to assess the genotype, gut microbiota, immune function biomarkers and enviromental exposures of subjects at risk of developing IBD.

Most genetic variants associated with IBD identified in Asia so far, through fine-mapping and candidate gene approach, vary according to ethnicity and nationalities. There is a lack of Genome wide association studies in Asia, and to identify novel Asian IBD-associated genes, such a study will require collaborative efforts between various centres in Asia in order to collect large number of samples. If the genetic and clinical heterogeneity of IBD in Asia is different from Western populations, response to medical therapy may also be different in our patients.

IBD represents an important public health problem affecting both the patient's education, working abilities, social life and quality of life. Apart from direct medical costs associated with hospitalisations and surgery, IBD is associated with substantial indirect costs related to activity impairment, especially since the onset of IBD typically occurs during adulthood. Little is also currently known of the cost of management of IBD in Asia. ${ }^{91}$ More likely than not, the incidence of IBD will continue to surge in Asia in the next decade. Effective research and development of IBD therapies will require network and collaboration between multiple centres in Asia. Although yet incorporated into practice in Asia, optimal patient management will need to move towards multi-disciplinary approach, including the active involvement of specialist dietitions, radiologist, surgeons, and in some tertiary IBD centres, IBD nurse specialist and psycologists. New systems and opportunities for education in IBD should be incorporated into training of specialists.

\section{CONCLUSION}

The rising incidence of IBD in Asia in the last two decades is a real phenomenon, which is considered to be the result of environmental changes secondary to economic growth and affluence. There appears to be variation in the incidence, prevalence and disease characterisitics between Asians of different nationalities and geography. Well conducted epidemiological studies of IBD will not only inform health care policy of the true scale of the disease in Asia but also offer the opportunity to help clinicians and researchers elucidate the role of enviromental factors and identify new aetiological factors responsible for this "IBD epidemic" in Asia.

\section{REFERENCES}

1. Danese S, Fiocchi C. Etiopathogenesis of inflammatory bowel 
diseases. World J Gastroenterol 2006;12:4807-4812.

2. Riis L, Vind I, Politi P, et al. Does pregnancy change the disease course? A study in a European cohort of patients with inflammatory bowel disease. Am J Gastroenterol 2006;101: 1539-1545.

3. Molinié F, Gower-Rousseau C, Yzet T, et al. Opposite evolution in incidence of Crohn's disease and ulcerative colitis in Northern France (1988-1999). Gut 2004;53:843-848.

4. Lakatos L, Mester G, Erdelyi Z, et al. Striking elevation in incidence and prevalence of inflammatory bowel disease in a province of western Hungary between 1977-2001. World J Gastroenterol 2004;10:404-409.

5. Sincić BM, Vucelić B, Persić M, et al. Incidence of inflammatory bowel disease in Primorsko-goranska County, Croatia, 2000-2004: a prospective population-based study. Scand J Gastroenterol 2006;41:437-444.

6. Lakatos PL, Fischer S, Lakatos L. Is the epidemiology of inflammatory bowel disease changing in Eastern Europe? Scand J Gastroenterol 2006;41:870-871.

7. Thia KT, Loftus EV Jr, Sandborn WJ, Yang SK. An update on the epidemiology of inflammatory bowel disease in Asia. Am J Gastroenterol 2008;103:3167-3182.

8. Lakatos PL. Recent trends in the epidemiology of inflammatory bowel diseases: up or down? World J Gastroenterol 2006;12: 6102-6108.

9. Goh K, Xiao SD. Inflammatory bowel disease: a survey of the epidemiology in Asia. J Dig Dis 2009;10:1-6.

10. Longobardi $T$, Bernstein $C N$. Health care resource utilization in inflammatory bowel disease. Clin Gastroenterol Hepatol 2006;4:731-743.

11. Longobardi T, Jacobs P, Wu L, Bernstein CN. Work losses related to inflammatory bowel disease in Canada: results from a National Population Health Survey. Am J Gastroenterol 2003;98:844-849.

12. Longobardi T, Jacobs P, Bernstein CN. Work losses related to inflammatory bowel disease in the United States: results from the National Health Interview Survey. Am J Gastroenterol 2003;98:1064-1072.

13. Feagan BG, Vreeland MG, Larson LR, Bala MV. Annual cost of care for Crohn's disease: a payor perspective. Am J Gastroenterol 2000;95:1955-1960.

14. Hou JK, El-Serag H, Thirumurthi S. Distribution and manifestations of inflammatory bowel disease in Asians, Hispanics, and African Americans: a systematic review. Am J Gastroenterol 2009;104:2100-2109.

15. Ouyang Q, Tandon R, Goh KL, Ooi CJ, Ogata H, Fiocchi C. The emergence of inflammatory bowel disease in the Asian Pacific region. Curr Opin Gastroenterol 2005;21:408-413.

16. Ooi CJ, Fock KM, Makharia GK, et al. The Asia-Pacific consensus on ulcerative colitis. J Gastroenterol Hepatol 2010; 25:453-468.

17. Ye BD, Jang BI, Jeen YT, Lee KM, Kim JS, Yang SK. Diagnostic guideline of Crohn's disease. Korean J Gastroenterol 2009;53:161-176.

18. Choi CH, Jung SA, Lee BI, Lee KM, Kim JS, Han DS. Diagnostic guideline of ulcerative colitis. Korean J Gastroenterol 2009;53:145-160.

19. Russel MG. Changes in the incidence of inflammatory bowel disease: what does it mean? Eur J Intern Med 2000;11:191-196.

20. Shivananda S, Lennard-Jones J, Logan R, et al. Incidence of inflammatory bowel disease across Europe: is there a difference between north and south? Results of the European Collaborative Study on Inflammatory Bowel Disease (EC-IBD). Gut 1996;39:690-697.

21. Loftus EV Jr. Clinical epidemiology of inflammatory bowel disease: incidence, prevalence, and environmental influences. Gastroenterology 2004;126:1504-1517.

22. Wilson J, Hair C, Knight R, Bell S. High incidence of inflammatory bowel disease in Australia: a prospective population-based Australian Incidence Study. Inflamm Bowel Dis 2010 (in press).

23. Ekbom A, Helmick C, Zack M, Adami HO. The epidemiology of inflammatory bowel disease: a large, population-based study in Sweden. Gastroenterology 1991;100:350-358.

24. Munkholm P, Langholz E, Nielsen OH, Kreiner S, Binder V. Incidence and prevalence of Crohn's disease in the county of Copenhagen, 1962-87: a sixfold increase in incidence. Scand J Gastroenterol 1992;27:609-614.

25. Binder V, Both $\mathrm{H}$, Hansen PK, Hendriksen C, Kreiner S, Torp-Pedersen K. Incidence and prevalence of ulcerative colitis and Crohn's disease in the County of Copenhagen, 1962 to 1978. Gastroenterology 1982;83:563-568.

26. Yoshida Y, Murata Y. Inflammatory bowel disease in Japan: studies of epidemiology and etiopathogenesis. Med Clin North Am 1990;74:67-90.

27. Yang SK, Yun S, Kim JH, et al. Epidemiology of inflammatory bowel disease in the Songpa-Kangdong district, Seoul, Korea, 1986-2005: a KASID study. Inflamm Bowel Dis 2008;14: 542-549.

28. Leong RW, Lau JY, Sung JJ. The epidemiology and phenotype of Crohn's disease in the Chinese population. Inflamm Bowel Dis 2004;10:646-651.

29. Kitahora T, Utsunomiya T, Yokota A. Epidemiological study of ulcerative colitis in Japan: incidence and familial occurrence. The Epidemiology Group of the Research Committee of Inflammatory Bowel Disease in Japan. J Gastroenterol 1995;30(Suppl 8):5S-8S.

30. Yao T, Matsui T, Hiwatashi N. Crohn's disease in Japan: diagnostic criteria and epidemiology. Dis Colon Rectum 2000; 43(10 Suppl):85S-93S.

31. Jiang L, Xia B, Li J, et al. Retrospective survey of 452 patients with inflammatory bowel disease in Wuhan city, central China. Inflamm Bowel Dis 2006;12:212-217.

32. Sood A, Midha V, Sood N, Bhatia AS, Avasthi G. Incidence and prevalence of ulcerative colitis in Punjab, North India. Gut 2003;52:1587-1590.

33. Lee YM, Fock K, See SJ, Ng TM, Khor C, Teo EK. Racial differences in the prevalence of ulcerative colitis and Crohn's disease in Singapore. J Gastroenterol Hepatol 2000;15:622-625.

34. Tan YM, Goh KL. Ulcerative colitis in a multiracial Asian country: racial differences and clinical presentation among Malaysian patients. World J Gastroenterol 2005;11:5859-5862.

35. Hilmi I, Tan YM, Goh KL. Crohn's disease in adults: observations in a multiracial Asian population. World $\mathrm{J}$ Gastroenterol 2006;12:1435-1438.

36. Higashi A, Watanabe Y, Ozasa K, Hayashi K, Aoike A, Kawai 
K. Prevalence and mortality of ulcerative colitis and Crohn's disease in Japan. Gastroenterol Jpn 1988;23:521-526.

37. Morita N, Toki S, Hirohashi T, et al. Incidence and prevalence of inflammatory bowel disease in Japan: nationwide epidemiological survey during the year 1991. J Gastroenterol 1995;(30 Suppl 8):1S-4S.

38. Yang SK, Hong WS, Min YI, et al. Incidence and prevalence of ulcerative colitis in the Songpa-Kangdong District, Seoul, Korea, 1986-1997. J Gastroenterol Hepatol 2000;15:1037-1042.

39. Sung JJ, Hsu RK, Chan FK, Liew CT, Lau JW, Li AK. Crohn's disease in the Chinese population. An experience from Hong Kong. Dis Colon Rectum 1994;37:1307-1309.

40. Lok $\mathrm{KH}$, Hung $\mathrm{HG}, \mathrm{Ng} \mathrm{CH}$, et al. Epidemiology and clinical characteristics of ulcerative colitis in Chinese population: experience from a single center in Hong Kong. J Gastroenterol Hepatol 2008;23:406-410.

41. Zheng JJ, Zhu XS, Huangfu Z, Gao ZX, Guo ZR, Wang Z. Crohn's disease in mainland China: a systematic analysis of 50 years of research. Chin J Dig Dis 2005;6:175-181.

42. Thia KT, Luman W, Jin OC. Crohn's disease runs a more aggressive course in young Asian patients. Inflamm Bowel Dis 2006;12:57-61.

43. Niriella MA, De Silva AP, Dayaratne AH, et al. Prevalence of inflammatory bowel disease in two districts of Sri Lanka: a hospital based survey. BMC Gastroenterol 2010;10:32.

44. Hugot JP. CARD15/NOD2 mutations in Crohn's disease. Ann N Y Acad Sci 2006;1072:9-18.

45. Ogura $\mathrm{Y}$, Bonen DK, Inohara N, et al. A frameshift mutation in NOD2 associated with susceptibility to Crohn's disease. Nature 2001;411:603-606.

46. Leong RW, Armuzzi A, Ahmad T, et al. NOD2/CARD15 gene polymorphisms and Crohn's disease in the Chinese population. Aliment Pharmacol Ther 2003;17:1465-1470.

47. Guo QS, Xia B, Jiang Y, Qu Y, Li J. NOD2 3020insC frameshift mutation is not associated with inflammatory bowel disease in Chinese patients of Han nationality. World $\mathrm{J}$ Gastroenterol 2004;10:1069-1071.

48. Inoue N, Tamura K, Kinouchi Y, et al. Lack of common NOD2 variants in Japanese patients with Crohn's disease. Gastroenterology 2002;123:86-91.

49. Croucher PJ, Mascheretti S, Hampe J, et al. Haplotype structure and association to Crohn's disease of CARD15 mutations in two ethnically divergent populations. Eur J Hum Genet 2003; 11:6-16.

50. Lee GH, Kim CG, Kim JS, Jung HC, Song IS. Frequency analysis of NOD2 gene mutations in Korean patients with Crohn's disease. Korean J Gastroenterol 2005;45:162-168.

51. Van Limbergen J, Russell RK, Nimmo ER, et al. IL23R $\mathrm{Arg} 381 \mathrm{Gln}$ is associated with childhood onset inflammatory bowel disease in Scotland. Gut 2007;56:1173-1174.

52. Tremelling M, Cummings F, Fisher SA, et al. IL23R variation determines susceptibility but not disease phenotype in inflammatory bowel disease. Gastroenterology 2007;132:16571664.

53. Yamazaki K, Onouchi Y, Takazoe M, Kubo M, Nakamura Y, Hata A. Association analysis of genetic variants in $I L 23 R$, ATG16L1 and 5p13.1 loci with Crohn's disease in Japanese patients. J Hum Genet 2007;52:575-583.
54. Yang SK, Park M, Lim J, et al. Contribution of $I L 23 R$ but not ATG16L1 to Crohn's disease susceptibility in Koreans. Inflamm Bowel Dis 2009;15:1385-1390.

55. Tosa M, Negoro K, Kinouchi Y, et al. Lack of association between IBD5 and Crohn's disease in Japanese patients demonstrates population-specific differences in inflammatory bowel disease. Scand J Gastroenterol 2006;41:48-53.

56. Aizawa $\mathrm{H}$, Kinoichui $\mathrm{Y}$, Negoro $\mathrm{K}$, et al. Lack of association between IRGM and Crohn's disease in Japanense patients demonstrates population-specific differences in inflammatory bowel disease. Gastroenterology 2008;134(4 Suppl 1):A460.

57. Franke A, Balschun T, Sina C, et al. Genome-wide association study for ulcerative colitis identifies risk loci at $7 \mathrm{q} 22$ and $22 \mathrm{q} 13$ (IL17REL). Nat Genet 2010;42:292-294.

58. Franke A, Balschun T, Karlsen TH, et al. Sequence variants in IL10, ARPC2 and multiple other loci contribute to ulcerative colitis susceptibility. Nat Genet 2008;40:1319-1323.

59. Silverberg MS, Cho JH, Rioux JD, et al. Ulcerative colitis-risk loci on chromosomes $1 \mathrm{p} 36$ and 12q15 found by genome-wide association study. Nat Genet 2009;41:216-220.

60. Juyal G, Amre D, Midha V, Sood A, Seidman E, Thelma BK. Evidence of allelic heterogeneity for associations between the NOD2/CARD15 gene and ulcerative colitis among North Indians. Aliment Pharmacol Ther 2007;26:1325-1332.

61. Chua KH, Hilmi I, $\mathrm{Ng} \mathrm{CC}$, et al. Identification of NOD2/CARD15 mutations in Malaysian patients with Crohn's disease. J Dig Dis 2009;10:124-130.

62. Sood A, Midha V. Epidemiology of inflammatory bowel disease in Asia. Indian J Gastroenterol 2007;26:285-289.

63. Cao Q, Si JM, Gao M, Zhou G, Hu WL, Li JH. Clinical presentation of inflammatory bowel disease: a hospital based retrospective study of 379 patients in eastern China. Chin Med J (Engl) 2005;118:747-752.

64. Park JB, Yang SK, Byeon JS, et al. Familial occurrence of inflammatory bowel disease in Korea. Inflamm Bowel Dis 2006;12:1146-1151.

65. Yamazaki K, McGovern D, Ragoussis J, et al. Single nucleotide polymorphisms in TNFSF15 confer susceptibility to Crohn's disease. Hum Mol Genet 2005;14:3499-3506.

66. Yamazaki K, Takazoe M, Tanaka T, et al. Association analysis of SLC22A4, SLC22A5 and DLG5 in Japanese patients with Crohn disease. J Hum Genet 2004;49:664-668.

67. Machida H, Tsukamoto K, Wen CY, et al. Association of polymorphic alleles of CTLA4 with inflammatory bowel disease in the Japanese. World J Gastroenterol 2005;11:41884193.

68. Yoshitake S, Kimura A, Okada M, Yao T, Sasazuki T. HLA class II alleles in Japanese patients with inflammatory bowel disease. Tissue Antigens 1999;53:350-358.

69. Asakura H, Tsuchiya M, Aiso S, et al. Association of the human lymphocyte-DR2 antigen with Japanese ulcerative colitis. Gastroenterology 1982;82:413-418.

70. Yang SK, Lim J, Chang HS, et al. Association of TNFSF15 with Crohn's disease in Koreans. Am J Gastroenterol 2008;103: 1437-1442.

71. Myung SJ, Yang SK, Jung HY, et al. HLA-DRB $1 * 1502$ confers susceptibility to ulcerative colitis, but is negatively associated with its intractability: a Korean study. Int $\mathrm{J}$ 
Colorectal Dis 2002;17:233-237.

72. Bin C, Zhirong Z, Xiaoqin W, et al. Contribution of rs11465788 in IL23R gene to Crohn's disease susceptibility and phenotype in Chinese population. J Genet 2009;88:191-196.

73. Luo Y, Xia B, Li C, Chen ZT, Ge LQ, Jiang T. Association of cytotoxic T lymphocyte antigen-4 promoter C-658T polymorphism with ulcerative colitis in Chinese. Zhonghua Yi Xue Yi Chuan Xue Za Zhi 2009;26:431-434.

74. Jiang Y, Xia B, Jiang L, et al. Association of CTLA-4 gene microsatellite polymorphism with ulcerative colitis in Chinese patients. Inflamm Bowel Dis 2006;12:369-373.

75. Zhou F, Xia B, Guo QS, et al. Cytotoxic T lymphocyte antigen-4 promoter gene polymorphism is significantly associated with ulcerative colitis. Zhonghua Nei Ke Za Zhi 2006;45:478-481.

76. Li KS, Wang BY, Liu SY, Yao SP, Guo L, Mao DW. The combination of polymorphisms within MCP-1 and IL-1beta associated with ulcerative colitis. Int J Immunogenet 2009; 36:135-139.

77. Li Y, Xia B, Lü M, et al. An association between MICB 0106 allele and ulcerative colitis in Chinese Han in Hubei province. Zhonghua Nei Ke Za Zhi 2008;47:213-216.

78. Lü M, Xia B, Ge L, et al. Role of major histocompatibility complex class I-related molecules A*A5.1 allele in ulcerative colitis in Chinese patients. Immunology 2009;128(1 Suppl): e230-e236.

79. Ding Y, Xia B, Lü M, et al. MHC class I chain-related gene A-A5.1 allele is associated with ulcerative colitis in Chinese population. Clin Exp Immunol 2005;142:193-198.

80. Chen B, Zeng Z, Hou J, Chen M, Gao X, Hu P. Association of interleukin-17F 7488 single nucleotide polymorphism and inflammatory bowel disease in the Chinese population. Scand J Gastroenterol 2009;44:720-726.

81. Juyal G, Midha V, Amre D, Sood A, Seidman E, Thelma BK. Associations between common variants in the MDR1 (ABCB1) gene and ulcerative colitis among North Indians. Pharmacogenet Genomics 2009;19:77-85.

82. Frangos CC, Frangos CC. Inflammatory bowel disease: reviewing an old study under a new perspective. Gut 2007;56: 1638-1639.

83. Jowett SL, Seal CJ, Pearce MS, et al. Influence of dietary factors on the clinical course of ulcerative colitis: a prospective cohort study. Gut 2004;53:1479-1484.

84. Hanauer SB. Inflammatory bowel disease: epidemiology, pathogenesis, and therapeutic opportunities. Inflamm Bowel Dis 2006;12(Suppl 1):3S-9S.

85. Krishnan A, Korzenik JR. Inflammatory bowel disease and environmental influences. Gastroenterol Clin North Am 2002;31:21-39.
86. Vind I, Riis $\mathrm{L}$, Jess $\mathrm{T}$, et al. Increasing incidences of inflammatory bowel disease and decreasing surgery rates in Copenhagen City and County, 2003-2005: a population-based study from the Danish Crohn colitis database. Am J Gastroenterol 2006;101:1274-1282.

87. Sakamoto N, Kono S, Wakai K, et al. Dietary risk factors for inflammatory bowel disease: a multicenter case-control study in Japan. Inflamm Bowel Dis 2005;11:154-163.

88. Jang JY, Kim HJ, Jung JH, et al. The role of smoking as a risk factor in inflammatory bowel diseases: single center study in Korea. Korean J Gastroenterol 2006;47:198-204.

89. Jiang L, Xia B, Li J, et al. Risk factors for ulcerative colitis in a Chinese population: an age-matched and sex-matched case-control study. J Clin Gastroenterol 2007;41:280-284.

90. Naganuma M, lizuka B, Torii A, et al. Appendectomy protects against the development of ulcerative colitis and reduces its recurrence: results of a multicenter case-controlled study in Japan. Am J Gastroenterol 2001;96:1123-1126.

91. Ouyang Q, Tandon R, Goh KL, et al. Management consensus of inflammatory bowel disease for the Asia-Pacific region. J Gastroenterol Hepatol 2006;21:1772-1782.

92. Chow DK, Leong RW, Lai LH, et al. Changes in Crohn's disease phenotype over time in the Chinese population: validation of the Montreal classification system. Inflamm Bowel Dis 2008;14:536-541.

93. Loftus EV Jr. Clinical epidemiology of inflammatory bowel disease: incidence, prevalence, and environmental influences. Gastroenterology 2004;126:1504-1517.

94. Ling KL, Ooi CJ, Luman W, Cheong WK, Choen FS, Ng HS. Clinical characteristics of ulcerative colitis in Singapore, a multiracial city-state. J Clin Gastroenterol 2002;35:144-148.

95. Jiang L, Xia B, Li J, et al. Retrospective survey of 452 patients with inflammatory bowel disease in Wuhan city, central China. Inflamm Bowel Dis 2006;12:212-217.

96. Rankin GB, Watts HD, Melnyk CS, Kelley ML Jr. National Cooperative Crohn's Disease Study: extraintestinal manifestations and perianal complications. Gastroenterology 1979;77: 914-920.

97. Wang YF, Zhang H, Ouyang Q. Clinical manifestations of inflammatory bowel disease: East and West differences. J Dig Dis 2007;8:121-127.

98. Park JB, Yang SK, Myung SJ, et al. Clinical characteristics at diagnosis and course of Korean patients with Crohn's disease. Korean J Gastroenterol 2004;43:8-17.

99. Dobbins WO 3rd. Dysplasia and malignancy in inflammatory bowel disease. Annu Rev Med 1984;35:33-48.

100. Bai AP, Ouyang Q, Hu RW. Basic research on inflammatory bowel disease in China. J Dig Dis 2007;8:194-197. 